\title{
Evaluating primary forest fuel rail terminals with dis- crete event simulation: A case study from Austria
}

\author{
U.J. Wolfsmayr, R. Merenda, P. Rauch, F. Longo, M. Gronalt
}

Wolfsmayr U.J., Merenda R., Rauch P., Longo F., Gronalt M., 2016. Evaluating primary forest fuel rail terminals with discrete event simulation: A case study from Austria. Ann. For. Res. 59(1): 145-164.

Abstract. Biomass rail transport is a useful alternative to unimodal truck transport for medium or long transport distances, if only a short road pre-haulage is required. Up to now primary forest fuels (PFF) are rarely transported on the rail network in Austria and rail terminals able to tranship notable volumes are not established yet. The objective of this study is to investigate the potentials of existing transhipment infrastructure for introducing and operating PFF terminals. Such PFF terminals enable a regular PFF supply to bioenergy plants and additionally provide opportunities for buffer storage and production processes like comminution. Three existing railway sidings in South, Central and Western Austria were chosen to serve as a multimodal transhipment hub with a road pre-haulage and a rail main-haulage for this case study. The logistic potential of these terminals was investigated, modelling the specific PFF supply chains, by means of a discrete event simulation. Simulation results provide daily and annual transhipment capacities and revealed bottlenecks in the terminal layout under different supply scenarios. Keywords biomass, bioenergy, terminal, simulation, multimodal transport, rail transport.

Authors. Ulrich J. Wolfsmayr (ulrich.wolfsmayr@boku.ac.at), P Rauch, Manfred Gronalt - University of Natural Resources and Life Sciences, Vienna; Rossana Merenda, Francesco Longo - University of Calabria, Italy.

Manuscript received April 018, 2015; revised June 08, 2015; accepted June 18, 2015; online first July 13, 2015.

\section{Introduction}

Biomass is a favourable source for energy due to ecological and economical reasons. Consequently, a growing market has been identified within Europe (FOROPA 2014, Wolfsmayr \&
Rauch 2014c). However, the source regions where biomass is available, i.e. forests, are often far away from the consumption regions where energy, i.e. heat and power, is needed. Therefore an effective transport network is necessary. In this paper we focus on a case 
study in Austria to illustrate how multimodal biomass transport can be implemented.

\section{PFF: supply and demand}

The gross domestic energy consumption ofAustria amounts to 1,427 PJ and is still dominated by fossil fuels. Renewable energy resources have a share of $26.1 \%$ and non-renewable combustible waste amounts to $2.5 \%$. The share of renewable energy splits into $61.4 \%$ bioenergy, $33 \%$ hydropower and smaller amounts of wind, geothermal, solar, etc. The remarkable amount of bioenergy, 228.6 PJ, is dominated by nearly $80 \%$ wood-based fuels (including black liquor) (Austrian Biomass Association 2013). There is only a little domestic production of oil and gas, thus with current demand levels this results in a great import dependency on oil, gas and coal (893 PJ); consequently, Austria imported in 2012 fossil fuels with a value of 12.8 billion euros, the highest value imports have ever been (Austrian Biomass Association 2013).

In Austria a great amount of primary forest fuels (PFF) is used for small-scale residential heating or smaller district heating systems (Haneder \& Furtner 2013). However, bigger plants, which use large amounts of PFF, have been built in recent years, inter alia due to an energy policy supporting bioenergy. Surveys of the Chamber of Agriculture show that there are 73 bioenergy plants with over $10 \mathrm{MW}$ in Austria (Herbert Haneder, Lower Austrian Chamber of Agriculture; pers. comm. in January 2014). Generally, the biggest plants are located in densely populated areas in the east of the country, while forest coverage is higher in the west of the country (Rauch \& Gronalt 2010). This results in a transportation need at distances where train transportation is competitive with road haulage. Additionally, the railroad is generally considered environmentally friendly if electricity from renewable sources is used (Behrends 2012).

Typical PFF transport chains, procurement systems and transport modes with a focus on Middle Europe can be found in Wolfsmayr and Rauch (2013) and they also provide a comprehensive literature review (2014a).

Worldwide, district heating systems and combined heat and power plants (CHP) have gained in importance in recent years and plant sizes have increased (Junginger et al. 2001, Lundmark 2006, Anbumozhi et al. 2010, Sauter et al. 2013). When the size of a bioenergy plant increases, the cost per unit energy produced decreases, due to scale effects; simultaneously, the biomass procurement area increases, resulting in greater influence of transport costs on total unit price (see e.g. Dornburg \& Faaij 2001, Gan \& Smith 2011, Jenkins \& Sutherland 2014). For longer transportation distances the transport density and therewith the energy density of the material is increased through chipping or bundling, the first one is mainly used for PFF. Here, the optimal location of chipping has a great influence on the procurement costs (Gronalt \& Rauch 2007).

\section{Benefits of train transport}

The modal shift from road to rail and waterway would make the supply less dependent on distance, reduce the energy consumption, and thus the transport costs for longer distances could be kept rather low (Börjesson \& Gustavsson 1996, Ranta \& Rinne 2006). Additionally, if bioenergy plants are located near densely populated areas according to the heat demand, the shift from truck to train would reduce undesirable effects on the general public, such as noise and air pollution or congested roads. Furthermore, trains using electricity from renewable sources have a lower global warming potential (Lindholm \& Berg 2005). Correspondingly, Jäppinen et al. (2013) illustrate that greenhouse gas emissions from forest fuel transport can be effectively reduced by using multimodal road-rail transport.

Due to the geographically dispersed procurement areas of biomass, an initial road pre- 
haulage is required in most of the cases; on long distances this can be followed by a rail main-haulage. Unimodal road transportation for biomass is generally appropriate for short distances, when flexibility is required due to plenty of small production sites, or when train or ship infrastructure are not available; train transport is applied for distances above 100 $\mathrm{km}$ and ship transport is applied for longer routes (Hamelinck et al. 2005). Due to highest distance fixed costs the waterway is only economical if there are more than $800 \mathrm{~km}$ of travel distance (Searcy et al. 2007). The use of two modes of transport leads to additional working processes and to compensate additional costs a minimum travel distance is necessary; it depends on the assortment, but at a distance of $200 \mathrm{~km}$ the total costs of a train transport system are lower than a comparable truck transport system (Tahvanainen \& Anttila 2011). Transport distance will increase when procurement areas get larger due to the increase in plant size. Consequently, there is a need for research on how to introduce multimodal transport chains in the bioenergy sector.

Nevertheless, the economical transport distance cannot be generally determined, but depends on the individual case: plant size, location, mode of transport, pre-treatments (chipping, baling), material properties, etc. (Junginger et al. 2001, Gronalt \& Rauch 2007).

One of the largest bioenergy plants in Austria, a 66 MW CHP in Vienna, entirely fired with PFF, can be supplied by road, rail and waterway (river Danube). A nearby industrial terminal serves as an area for collecting, storing and chipping, from where the chips are delivered to the plant on trucks (Madlener \& Bachhiesl 2007). Train transportation is preferable above $96 \mathrm{~km}$ in terms of energy requirements and above $250 \mathrm{~km}$ in terms of cost-effectiveness (Madlener \& Bachhiesl 2007). In Switzerland a $30 \mathrm{MW}$ bioenergy plant in Basel with rail connection needs for economic train transport distances well beyond $100 \mathrm{~km}$ (Madlener
\& Vögtli 2008). Recently, it has been reported that train transport is seldom used for PFF in Austria (Wolfsmayr \& Rauch 2014b).

Subsequently, the objective of this study is to investigate the capability of existing transhipment infrastructure (rail sidings, storage areas, and access roads) for introducing PFF rail terminals, through a computer simulation model. Such terminals should enable the regular delivery of raw material to bioenergy plants, additionally they function as storage areas and places for comminution.

For the computer model three existing layouts had been adapted to provide a multimodal transhipment hub, with a road pre-haulage and a rail main-haulage. Through simulation the potentials of these PFF terminals were investigated. Furthermore, the simulation provided quantities of stock, in- and outgoing forest fuel volumes on a daily basis and total annual quantities of processed material. Additionally, two scenarios were simulated: a regular scenario, which is realistic for a long-term economic utilisation of the terminals and a disturbance scenario, where arrival frequency of incoming trucks is doubled and different factors are modified. The simulation should be of guidance for future decisions on the PFF supply chain.

This study illustrates a multimodal PFF supply chain. It shows Austrian circumstances: loading sidings and attached storage areas are relatively small compared with for example Sweden. Nevertheless, they still allow regular deliveries of reasonable amounts of woodchip to bioenergy plants. Currently, rail transport is rarely used in Austria, thus this study elucidates the terminal processes and furthermore highlights that it is technically possible to establish a year-round operating PFF terminal.

\section{Material and methods}

The following chapter describes the locations where the PFF terminals were modelled, and 
the simulation of terminal processes, namely the incoming and outgoing logistics. Moreover, factors influencing the model and performance values are illustrated. The basic assumptions rely on observations made in the field.

\section{Terminal sites}

Three different PFF rail terminals in Austria were used in the model. They were selected due to geographical reasons, the supply of PFF and, additionally, due to the availability of storage areas for energy roundwood and wood chips at the terminals as well as a loading siding, which is long enough for at least 6 wagons. The length of the siding and the approximate size and dimensions of storage areas were measured from digital orthophotos. All three are existing sidings, where the loading of different types of wood assortments for rail transport is possible. Although wood may be transported from the selected terminal sites, the intense use, which is modelled, does not reflect the current usage.

The selection includes three locations, (i) St. Martin am Grimming (Central Austria), (ii) Möllbrücke (Southwest Austria), and (iii) Schwaz (West Austria). The approximate distances between these terminals and Vienna are $270 \mathrm{~km}, 400 \mathrm{~km}$, and $520 \mathrm{~km}$, respectively. For the simulation the terminals are labelled as A1, $\mathrm{A} 2$ and $\mathrm{B}$, respectively. The terminals $\mathrm{A} 1$ and A2 were larger and could provide two storage areas: one for uncomminuted wood and one for woodchips. In contrast, terminal B was smaller and had only storage space for uncomminuted wood. A companion paper (Etlinger et al. 2014) discusses different layout options for roundwood terminals in order to define efficient wood terminal structures.

Storage areas for roundwood or other uncomminuted assortments of PFF do not need to be on paved ground. Chip piles require paved ground to avoid contamination - especially stones - in the material, and loading and cleaning of the area is easier. However, if such infrastructure is not available additional investments are necessary. If chip storage on paved ground is possible, more assortments can be delivered to the terminal, for example forest residues that have been chipped at a forest landing.

Terminal A1 had a chip storage capacity of $2,500 \mathrm{~m}^{3}$ of loose chips and a roundwood storage capacity of $1,250 \mathrm{~m}^{3}$ solid. Terminal A2 had a chip storage capacity of $3,125 \mathrm{~m}^{3}$ of loose chips and a roundwood storage capacity of $1,560 \mathrm{~m}^{3}$ solid. Terminal B provided only an unpaved roundwood storage area, with a capacity of 2,800 $\mathrm{m}^{3}$ solid.

Within this paper the term energy roundwood is used to refer to low quality roundwood (e.g. with rot), small diameter roundwood or roundwood from species that are not suitable for industrial use (e.g. many hardwood species).

\section{Road Pre-Haulage}

For truck transport two types of PFF are used in the simulation: (i) energy roundwood (low quality or small diameters, see above), and (ii) wood chips, produced at the forest landing. While the first one is carried on a log truck, the latter one is carried on a $90 \mathrm{~m}^{3}$-walking floor truck.

\section{Chipping}

Chipping at all terminals was done by a large mobile chipper. The chipping at the terminals was either modelled as direct chipping into containers located on the wagons or chipping on the chip storage on paved ground. For terminal A1 and A2 a productivity of $240 \mathrm{~m}^{3}$ of chips per hour was modelled, for terminal B a lower productivity of $180 \mathrm{~m}^{3}$ of chips per hour was used (this step included the loading of the wagons). If the same chipper type was used, a reduced performance of around 30\% was documented in the field trials (mainly due to chipper movement along the rail track). For terminals $\mathrm{A} 1$ and $\mathrm{A} 2$ an additional loading 
process with wheel loaders was necessary; the wheel loader was modelled with a productivity of $240 \mathrm{~m}^{3}$ chips loaded per hour (also observed in field trials). The simulation uses a conversion factor of 3 .

\section{Direct chipping into train wagons}

Prior to building the simulation model, a detailed field study had been made. Energy roundwood was transported on trucks to a terminal in the town of Netolice (Czech), where it was stored, chipped, loaded and further transported to a bioenergy plant in Pilsen on the railroad using the container type described below. Both loading methods were used, the common wheel loader method, and the innovative direct chipping method as documented in Wolfsmayr et al. (2013). The latter method allows omitting a work step and thus time savings are possible; in the simulation it is applied at terminal $\mathrm{B}$. The terminals A1 and A2 are simulated with the common method using a wheel loader. Fig. 1 shows both methods as observed in the field.

\section{Train Main-Haulage}

For train transport only wood chips are used in the simulation. The chips are carried in $20 \mathrm{ft}$ containers (WoodTainer XXL, with a volume of $48 \mathrm{~m}^{3}$ ), three of which on a $60 \mathrm{ft}$ wagon. The benefits of this system are inter alia the dimensions of ISO standard containers, which allow transportation on container wagons, and the fast and easy rotary unloading with special forklifts (Innofreight 2013). As illustrated above, the WoodTainer system is used for permanent chip supply to a bioenergy plant in the Czech Republic. In Austria it is only used to ship high quality chips from sawmills to pulp and chipboard mills. Some trials with PFF in Austria were carried out, but no regular use has been established yet (Hannes Pichler, Innofreight Speditions $\mathrm{GmbH}$, pers. comm. in 2013).

In Austria an adequate wagon type is the "Sgnss", which is a $60 \mathrm{ft}$ wagon with a max. length over buffer of $19.8 \mathrm{~m}$. Depending on the existing sidings at the three potential terminals a maximum number of wagons (12 or 6 , respectively) was estimated. However, the maximum length of a block train in Austria is $650 \mathrm{~m}$ plus locomotive. For terminal B, where direct chipping is modelled, always the maximum number of wagons for the loading sidings (block of six wagons) is ordered at a time in order to maximize chipping efficiency.

\section{Scenarios}

Two scenarios were calculated: First, a so-
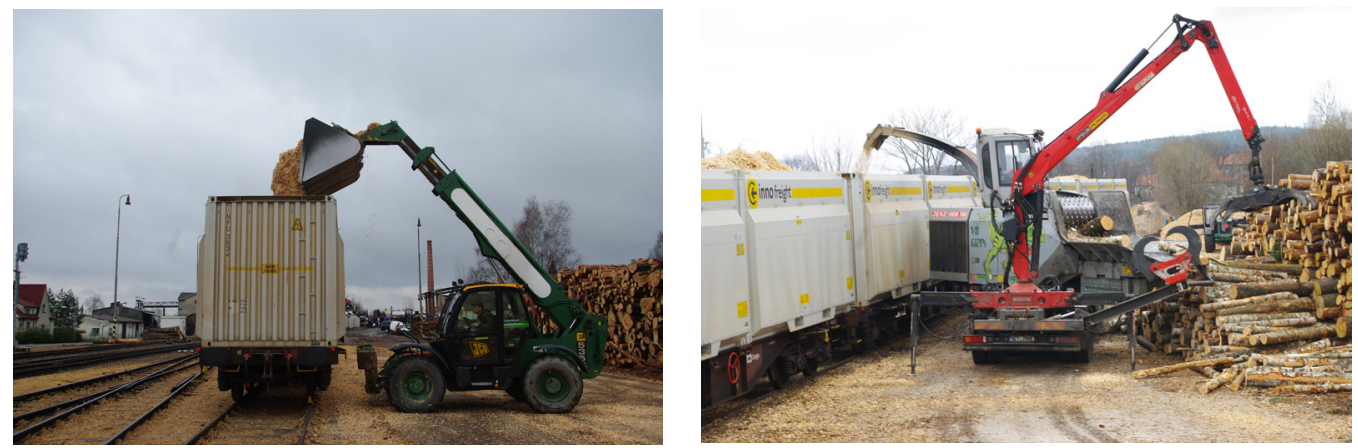

Figure 1 Loading with a wheel loader (left) and direct chipping in the container (right). Pictures: Wolfsmayr 
called "regular PFF supply scenario" in which planned harvest activities are taking place (denoted "regular"). The used material flows should be possible all-year round for a longer period to provide a transhipment node in a multimodal PFF supply chain. Second, a scenario with oversupply caused by storm damage and/ or massive bark beetle infestations (denoted "disturbance", cf. Rauch 2010) with higher volumes was used in the simulation. Here, the number of truck deliveries is doubled and the train capacities are enlarged (see Table 1). Additionally, the storage possibilities are enlarged along with necessary concomitant adaptation of additional areas next to the existing storage surfaces. However, the length of loading sidings, and therewith the capacities for loading trains, remained unchanged. Operational procedures and parameters were kept constant. On running the simulation with 2 sets of quantities for material flow, we were able to identify factors influencing the efficiency of the system.

\section{Simulation of terminal processes}

The terminal processes were designed in ADONIS using business process modelling (BPMN 2.0) and are based on the field observations, especially the above mentioned supply chain to the bioenergy plant in Pilsen. Based on these processes the discrete event simulation was built in AnyLogic version 6 . The simulation starts on January 2 and ends on December 31. Trucks enter the terminal daily, from Monday to Friday, between 6 am and $6 \mathrm{pm}$. Trucks entering the terminal represent customer orders for PFF train transport that should be fulfilled by the terminal.

Table 1 Factors of simulated scenarios

\begin{tabular}{lll}
\hline & Regular scenario & Disturbance scenario \\
\hline TERMINAL A1 & & \\
\hline Chip stock capacity & $2,500 \mathrm{~m}^{3}$ loose & $3,750 \mathrm{~m}^{3}$ loose \\
Energy roundwood stock capacity & $1,250 \mathrm{~m}^{3}$ solid & $1,875 \mathrm{~m}^{3}$ solid \\
Chip trucks per day & 3 & 6 \\
Log trucks per day & 5 & 10 \\
Number of trains per day & 1 & 2 \\
Type of train order & Single wagon & Fixed number of wagons \\
\hline TERMINAL A2 & & \\
\hline Chip stock capacity & $3,125 \mathrm{~m}^{3}$ loose & $4,688 \mathrm{~m}^{3}$ loose \\
Energy roundwood stock capacity & $1,560 \mathrm{~m}^{3}$ solid & $2,340 \mathrm{~m}^{3}$ solid \\
Chip trucks per day & 5 & 10 \\
Log trucks per day & 5 & 10 \\
Number of trains per day & 1 & 2 \\
Type of train & Single wagon & Fixed number of wagons \\
\hline TERMINAL B & & $4,200 \mathrm{~m}^{3}$ solid \\
\hline Energy roundwood stock capacity & $2,800 \mathrm{~m}^{3}$ solid & 20 \\
Log trucks per day & 10 & 2 \\
Number of trains per day & 1 & Fixed number of wagons \\
Type of train * & Fixed number of wagons &
\end{tabular}

Note. * In Terminal B the type of train is not changed, thus this terminal has only 3 factors. 
Fig. 2 shows the flow chart for the incoming logistics processes in terminal A1 and A2 on which the simulation is built. Arriving log trucks carry energy roundwood and are accepted if the additional volumes can be un- loaded (storage volume is well below maximum level), otherwise they are sent away and are counted as lost trucks due to overflow. The trucks wait in a queue until unloading, because only one truck at a time can be unloaded. If

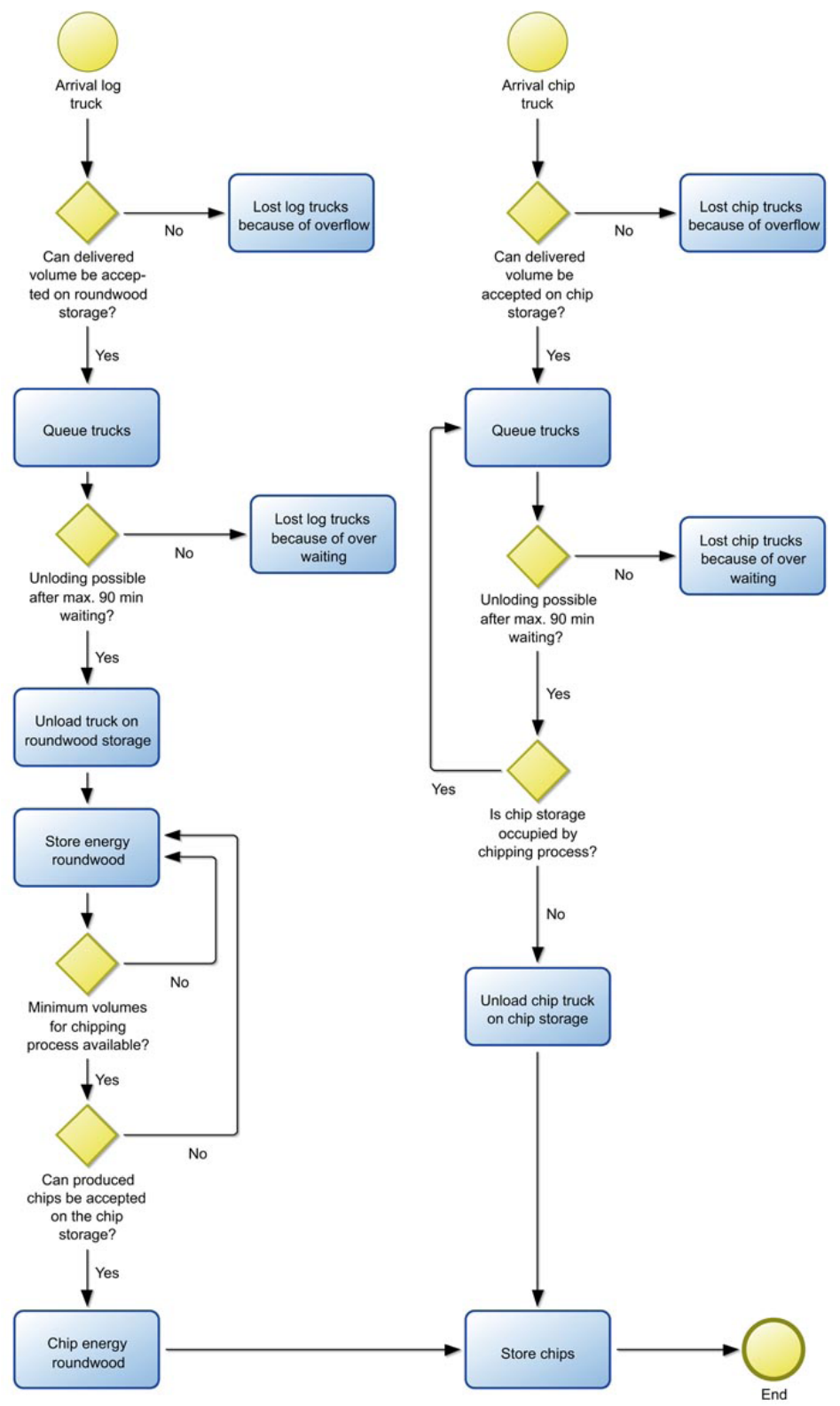

Figure 2 Incoming logistics for terminals A1 and A2 (flow chart; ADONIS) 
the waiting time exceeds 90 minutes they are sent away and are counted as lost trucks due to over waiting (i.e. exceeding maximum waiting time). The load volume was modelled as triangular distribution $\left(20,25,30 \mathrm{~m}^{3}\right.$ energy roundwood per truck). Similarly, the incoming chip trucks were modelled (load volume with triangular distribution: $80,85,90 \mathrm{~m}^{3}$ chips per truck). The unloading times are expressed in minutes by triangular distributions for both, chip trucks $(10,15,20)$ and log trucks $(25$, $30,45)$. The simulation records the number of lost trucks due to over waiting or overflow and consequently how many $\mathrm{m}^{3}$ of $\operatorname{logs}$ or $\mathrm{m}^{3}$ of chips are lost. Furthermore it gathers the waiting time in the queue, the unloading time and the lead time from arrival to departure.

There are two requirements to start the chipping process: at first, enough energy roundwood needs to be in storage to occupy the chipper for at least 4 hours; second, enough capacity in the chip storage to store the additional chips. The chipper in the terminals A1 and A2 has an output of $240 \mathrm{~m}^{3}$ of chips per hour. Chips are stored at the chip storage. During the chipping process, no chip trucks can enter the terminal, because otherwise the chip storage is at risk of overflowing.

Fig. 3 shows the flow chart for the outgoing logistics processes in terminal A1 and A2. Prior to starting the simulation run, one can choose, depending on the selected scenario, if the terminals can order a variable number of wagons per train (every day a terminal can require the number of wagons needed) or a fixed number of wagons (if a train is ordered it delivers a fixed number of wagons: 12 for Terminal A1, 6 for Terminal A2). If the scenario uses a variable number of wagons per train, every day at 6 am the model checks the volume of chips stored; if this quantity is more than the capacity of 2 wagons the necessary number of wagons needed is ordered. If the scenario uses a fixed number of wagons per train, every day at 6 am the model checks if the storage volume is sufficient to fill all those wagons completely.
In the disturbance scenario two trains per day can be ordered, in this case the ordering is repeated at $12 \mathrm{pm}$. One $60 \mathrm{ft}$ wagon carries three WoodTainer XXL, with a volume of $48 \mathrm{~m}^{3}$ each, resulting in $144 \mathrm{~m}^{3}$ chips to be loaded on every wagon. Note that the number of wagons is still below a block train in practice, but the number of wagons is limited with the length of the loading sidings and shunting would be needed, but operations of the railway company were not part of this simulation. After train arrival, the loading process can start using a wheel loader with a performance of $240 \mathrm{~m}^{3}$ per hour. When loaded, the train leaves for the bioenergy plant.

Fig. 4 shows the flow chart for the logistics processes in terminal B. Arriving log trucks loaded with energy roundwood are accepted if the additional volumes can be unloaded (storage volume is fairly below maximum level), otherwise they are sent away and are counted as lost trucks due to overflow. Trucks wait in a queue until unloading, because only one truck at a time can be unloaded. If waiting exceeds 90 minutes, they are sent away and are counted as lost trucks due to over waiting. The trucks unload their material onto the roundwood storage (unloading time in minutes, as observed in the industry, is defined by a triangular distribution, 25, 30, 45).

In terminal $\mathrm{B}$ the raw material is directly chipped into WoodTainer XXL located on wagons (as recorded in the field at the terminal Netolice, Czech Republic, see above). To efficiently use the chipper the throughput per chipping/loading cycle should be maximized, thus always the maximum number of 6 wagons (with 3 containers each) is ordered to fully utilize the length of the loading sidings. Hence, an order is only made if there is enough material to fill all containers. For the chipping/ loading process always the number of 6 wagons is ordered, because the chipper should be used efficiently (e.g. setup times). Two chipping/loading processes per day are possible. The chipper capacity in terminal B is slightly 


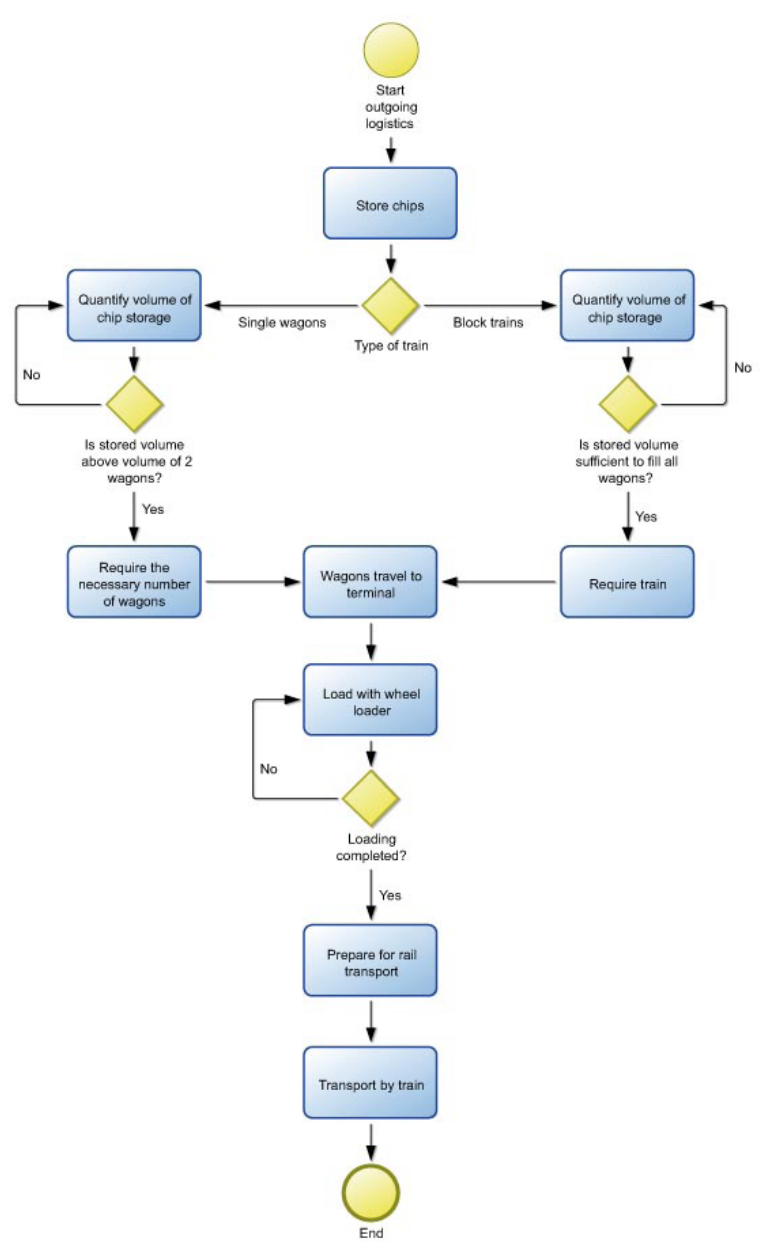

Figure 3 Outgoing logistics for terminals A1 and A2 (flow chart; ADONIS)

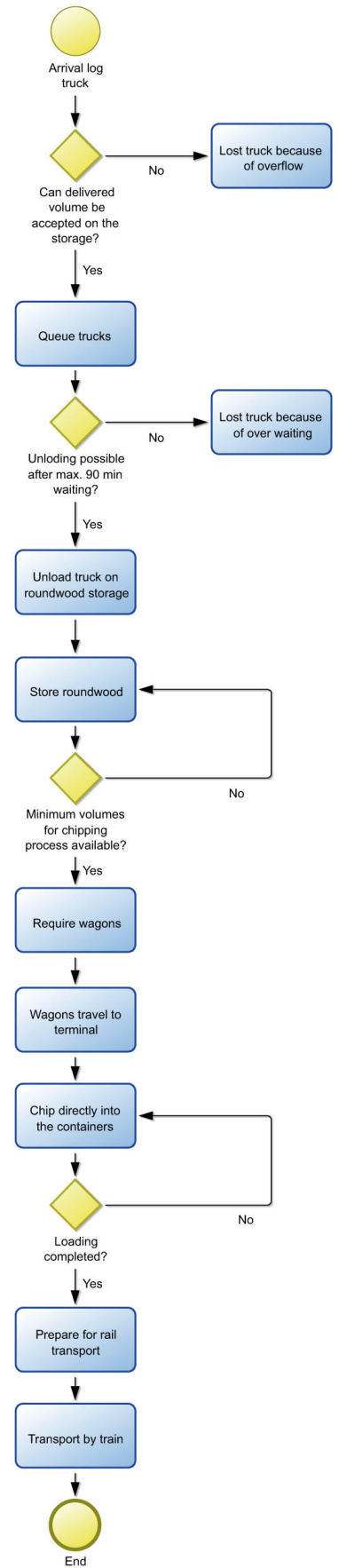

Figure 4 Incoming and outgoing logistics for terminal B (flow chart; ADONIS) 
below the other terminals $\left(180 \mathrm{~m}^{3}\right.$ of chipped material per hour, see above).

\section{Case study factors}

The two scenarios, a regular scenario with lower quantities and a disturbance scenario with high quantities of material to be transhipped at the terminals, differ in a number of basic assumptions (see Table 1). Moreover, the simulation allows changing these assumptions individually and thus it is possible to apply statistical design of experiments. Model properties that can be changed are termed factors (Callahan et al. 2006). Subsequently, by varying these factors (considered as independent variables for statistical analyses) it is possible to generate a statistical analysis with full factorial design, which enabled us to detect interactions ( $\mathrm{k}=$ number of factors). Thus, each of the $\mathrm{k}$ factors was set at two levels ("low" and "high" level). The model applied a factorial $2^{6}$ design for terminals A1 and A2 and factorial $2^{3}$ design for terminal $\mathrm{B}$, respectively.

For terminal A1 and terminal A2, 6 factors with 2 values each were considered. Every experiment was repeated 3 times in order to consider variations due to stochastic inputs. Full factorial design was applied, thus 26x3 runs of each terminal enabled us to study possible combinations. For terminal B 3 factors with 2 values each were considered, resulting in $23 \times 3$ runs. The performance values (also referred to as responses, cf. Callahan et al. 2006) were used to control the efficiency of the terminals - see Table 2 (the abbreviations CT and LT are used to refer to chip trucks and log trucks, respectively). The combination of factor values and the associated responses was recorded for each run. Supplementary to this, an analysis of

Table 2 Performance values for analysing terminals (CT: chip truck; LT: log truck)

\begin{tabular}{|c|c|c|c|c|}
\hline Tern & inals & & Performance value & Explanation \\
\hline A1 & A2 & & CT Over Waiting & $\begin{array}{l}\text { Percentage of chip trucks that cannot be dispatched, because } \\
\text { waiting in the queue exceeds } 90 \text { minutes, compared to the total } \\
\text { number of incoming chip trucks }\end{array}$ \\
\hline A1 & A2 & & CT Over Flow & $\begin{array}{l}\text { Percentage of chip trucks that cannot be dispatched, because } \\
\text { the storage capacity is at its limit, compared to the total number } \\
\text { of incoming chip trucks }\end{array}$ \\
\hline A1 & A2 & B & LT Over Waiting & $\begin{array}{l}\text { Percentage of log trucks that cannot be dispatched, because } \\
\text { waiting in the queue exceeds } 90 \text { minutes, compared to the total } \\
\text { number of incoming log trucks }\end{array}$ \\
\hline A1 & A2 & B & LT Over Flow & $\begin{array}{l}\text { Percentage of log trucks that cannot be dispatched, because the } \\
\text { storage capacity is at its limit, compared to the total number of } \\
\text { incoming log trucks }\end{array}$ \\
\hline A1 & A2 & & Mean CT Waiting Time & $\begin{array}{l}\text { Average value of the waiting time of the chip trucks that enter } \\
\text { the terminal }\end{array}$ \\
\hline A1 & A2 & B & Mean LT Waiting Time & $\begin{array}{l}\text { Average value of the waiting time of the log trucks that enter } \\
\text { the terminal }\end{array}$ \\
\hline A1 & $\mathrm{A} 2$ & $\mathrm{~B}$ & Number of Trains & Number of trains that are loaded at the terminal during one year \\
\hline A1 & A2 & $\mathrm{B}$ & Chips Out & Quantity of chips delivered via train \\
\hline A1 & A2 & & Fill Rate CT & $\begin{array}{l}\text { Ratio between dispatched chip trucks and totally arrived chip } \\
\text { trucks }\end{array}$ \\
\hline A1 & $\mathrm{A} 2$ & B & Fill Rate LT & $\begin{array}{l}\text { Ratio between dispatched log trucks and totally arrived log } \\
\text { trucks }\end{array}$ \\
\hline
\end{tabular}


variance (ANOVA) was calculated to investigate the statistical significance.

\section{Results}

The results here show: firstly, the results of the regular scenario; secondly, a report on the disturbance scenario, showing the effects of higher volumes; and thirdly, a statistical analysis showing the influence of different factors on the performance of the PFF terminals.

\section{Regular scenario}

Stock utilisation. On average, the chip storage of the largest terminal in the simulation - A2 - used more than $75 \%$ of its capacity for $60 \%$ of the days (Fig. 5). The storage for energy roundwood of terminal A2 mainly used less than $25 \%$ of its capacity and never came close to its level of capacity (Fig. 5). The mean of the chip stock was 2,393 $\mathrm{m}^{3}$ (standard deviation $23 \%$ ), the mean of energy roundwood stock was $218 \mathrm{~m}^{3}$ (standard deviation 51\%).

The situation in terminal A1 was similar: the chip storage used more than $75 \%$ of its capacity during $40 \%$ of the days (mean of the chip stock level was $1,684 \mathrm{~m}^{3}$ ); the energy roundwood storage mainly used less than $25 \%$ of its capacity (mean of roundwood stock was 220 $\left.\mathrm{m}^{3}\right)$.

Terminal B provided a storage area for energy roundwood only, see Fig. 6. For most of the time the stock utilisation was below 50\% of its capacity; the mean was $1,124 \mathrm{~m}^{3}$ and the quantity of the stored material did not exceed $1,600 \mathrm{~m}^{3}$.

Incoming logistics Terminal A1. The performance value "CT Over Waiting" resp. "LT Over Waiting” was calculated as a proportion of chip resp. log trucks that waited more than 90 minutes for unloading at the terminal, and therefore left the terminal without unloading their freight. For chip trucks resp. log trucks these values were $0 \%$ resp. $0.3 \%$. If the load volume of an arriving truck would lead to overflow in the storage, the truck was
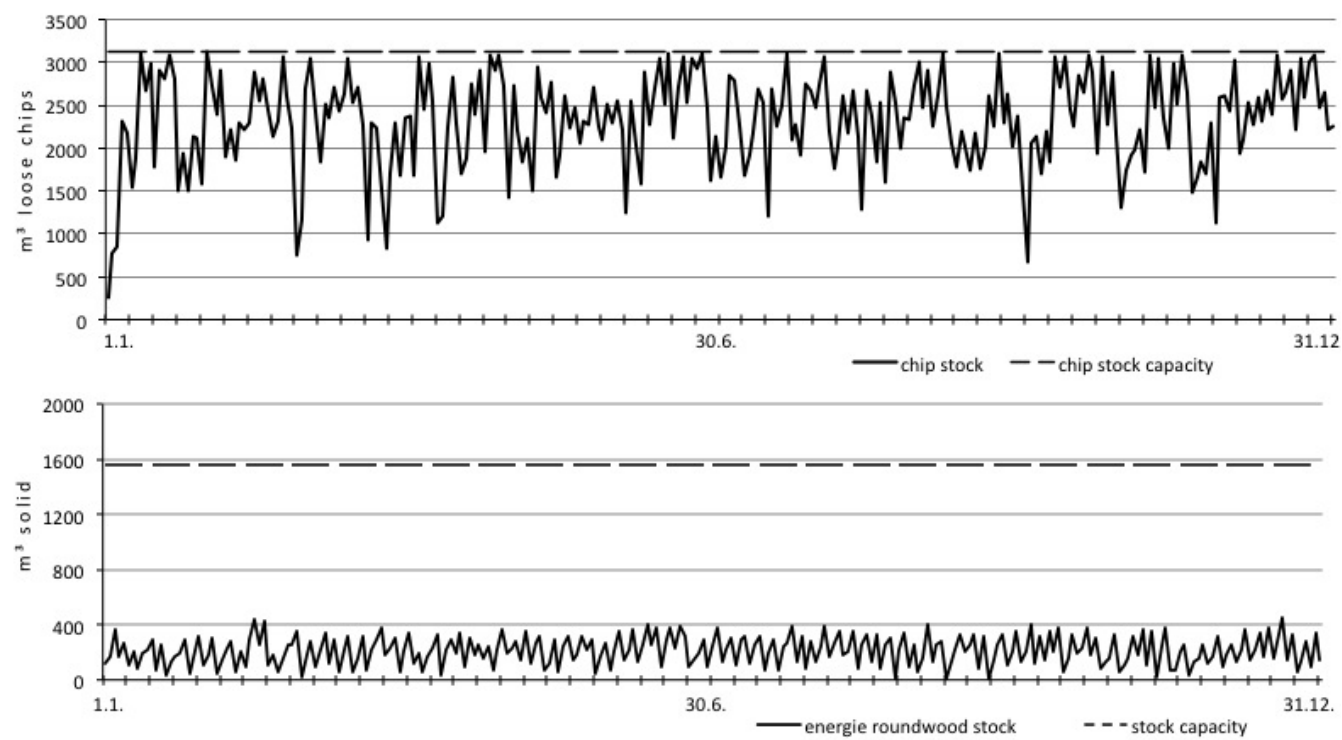

Figure 5 Terminal A2 - stock development on a daily basis over a year. N.B. Top diagram shows the chip stock; Bottom diagram shows the energy roundwood stock 


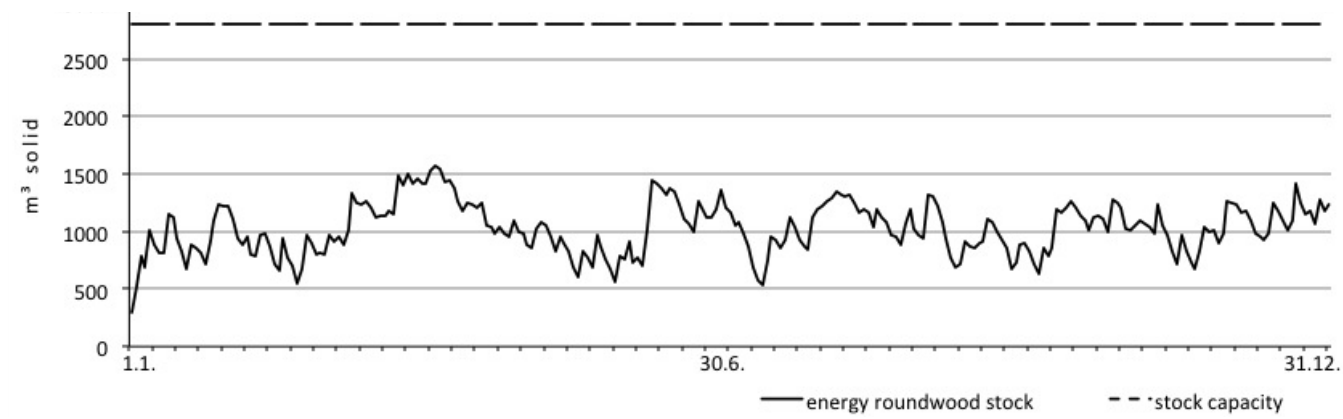

Figure 6 Energy roundwood stock at terminal B on a daily basis over a year

sent away. The percentage of lost chip trucks because of overflow compared to the total number of incoming chip trucks was $3.4 \%$ (performance value "CT Over Flow"); for log trucks this value was 0 (performance value "LT Over Flow"). Subsequently, the terminal fill rate, which is the ratio between dispatched trucks and arrived trucks, was $96.6 \%$ for chip trucks (performance value "Fill Rate CT") and 99.7\% for log trucks (performance value "Fill Rate LT").

The time between the trucks' entry in the system and their exit is usually denoted as lead time, and the average value during a year in the regular scenario was 43 minutes (standard deviation $36 \%$ ) for the chip trucks and 54 minutes (standard deviation 30\%) for the $\log$ trucks. The average waiting time in the queue, that is the time between the trucks' entry in the terminal and the start of unloading, was 8 minutes for chip trucks (performance value "Mean CT Waiting Time") and 8 minutes for log trucks (performance value "Mean LT Waiting Time").

Incoming logistics Terminal A2. The percentage of undispatched trucks because of over waiting was $0.4 \%$ for chip trucks ("CT Over Waiting") and $0.3 \%$ for log trucks ("LT Over Waiting"). The percentage of undispatched trucks because of overflow was $6 \%$ for chip trucks and $0 \%$ for log trucks ("CT Over Flow" and "LT Over Flow"). Subsequently, the terminal fill rate was $93.6 \%$ for chip trucks ("Fill Rate CT") and 99.7\% for log trucks ("Fill Rate LT"). The average lead time was 46 minutes (standard deviation 38\%) for chip trucks and 54 minutes (standard deviation $30 \%$ ) for log trucks. The average waiting time in the queue was 11 and 9 minutes for chip and log trucks, respectively ("Mean CT Waiting Time" and "Mean LT Waiting Time").

Incoming logistics Terminal B. The percentage of lost trucks amounted to $1.8 \%$ and the terminal fill rate was $98.2 \%$. The average value for the lead time was 61 minutes (standard deviation 37\%), and for the waiting time 15 minutes. The discussed performance values are compiled in Table 3.

Train logistics in the Terminals. In each scenario every terminal has a maximum number of possible train arrivals per day as well as maximum number of wagons per train (due to the length of the sidings at the terminal). The number of wagons ordered varies according to the quantity of material shipped. Terminal B accepts only a block of 6 wagons. Due to non-business days, the terminal operated on only 261 days of the observed year. Table 4 shows the average number of wagons per train and the number of arrivals in that year.

Material flow in the terminals. Table 5 shows the material flow in a one-year period. Note that when the material is chipped, $1 \mathrm{~m}^{3}$ energy roundwood yields $3 \mathrm{~m}^{3}$ of chips. 
Table 3 Incoming logistics per terminal, regular scenario

\begin{tabular}{llll}
\hline Performance values & Regular Scenario & & \\
\hline & $\mathrm{A} 1$ & $\mathrm{~A} 2$ & $\mathrm{~B}$ \\
CT Over Waiting & $0 \%$ & $0.4 \%$ & - \\
CT Over Flow & $3.4 \%$ & $6 \%$ & - \\
LT Over Waiting & $0.3 \%$ & $0.3 \%$ & $1.8 \%$ \\
LT Over Flow & $0 \%$ & $0 \%$ & $0 \%$ \\
Mean CT Waiting Time & $8 \mathrm{~min}$ & $11 \mathrm{~min}$ & - \\
Mean LT Waiting Time & $8 \mathrm{~min}$ & $9 \mathrm{~min}$ & $15 \mathrm{~min}$ \\
Fill Rate CT & $96.6 \%$ & $93.6 \%$ & - \\
Fill Rate LT & $99.7 \%$ & $99.7 \%$ & $98.2 \%$ \\
\hline
\end{tabular}

Table 4 Train logistics regular scenario

\begin{tabular}{lllll}
\hline Terminal & $\begin{array}{l}\text { Max. number of } \\
\text { trains per day }\end{array}$ & $\begin{array}{l}\text { Max. number of } \\
\text { wagons per train }\end{array}$ & $\begin{array}{l}\text { Average number of } \\
\text { wagons per train }\end{array}$ & Train arrivals total \\
\hline A1 & 1 & 12 & 7.5 & 140 \\
A2 & 1 & 6 & 5.5 & 251 \\
B & 1 & 6 (fixed number) & 6.0 & 225 \\
\hline
\end{tabular}

Table 5 Material flow in the terminals, regular scenario

\begin{tabular}{lllllc}
\hline Terminal & $\begin{array}{l}\text { Input } \\
\text { chips }\left(\mathrm{m}^{3}\right)\end{array}$ & $\begin{array}{l}\text { Input energy } \\
\text { roundwood }\left(\mathrm{m}^{3}\right)\end{array}$ & $\begin{array}{l}\text { Output chips } \\
\left(\mathrm{m}^{3}\right)\end{array}$ & $\begin{array}{l}\text { Storage chips } \\
\left(\mathrm{m}^{3}\right)\end{array}$ & $\begin{array}{l}\text { Storage energy } \\
\text { roundwood }\left(\mathrm{m}^{3}\right)\end{array}$ \\
\hline A1 & 56,708 & 31,790 & 150,768 & 1,013 & 99,000 \\
A2 & 106,416 & 31,444 & 198,576 & 1,692 & 160,000 \\
B & & 65,586 & 192,672 & & 1,362 \\
\hline
\end{tabular}

\section{Disturbance scenario}

Stock utilisation. The disturbance scenario investigated how increasing volumes affect terminal performance. In terminal A2 the storage volume of chips exceeded $90 \%$ of the storage capacity on $86 \%$ of the days. Stored energy roundwood exceeded $50 \%$ of the storage capacity on $74 \%$ of the days; however, only on one out of ten days did it exceed $80 \%$ of the capacity. Fig. 7 illustrates the stock development for chips and energy roundwood. The mean value of the chip stock was $4,447 \mathrm{~m}^{3}$ (standard deviation $8 \%$ ), the mean value of energy roundwood stock was $1,375 \mathrm{~m}^{3}$ solid (standard deviation $35 \%$ ).

In terminal A1 the chip storage used more than $90 \%$ of its capacity on $60 \%$ of the days (mean value of the chip stock level was 3,240 $\mathrm{m}^{3}$; standard deviation 20\%); the energy roundwood storage mainly used less than 50\% of its capacity, only on one out of ten days did the stored volume exceed $50 \%$ of the capacity (mean value of energy roundwood stock is 566 $\mathrm{m}^{3}$ solid, standard deviation $50 \%$ ).

Terminal B provided a storage area for energy roundwood only and the utilisation never exceeded $50 \%$ of the storage capacity (mean value of the stored volume was $1,375 \mathrm{~m}^{3}$; standard deviation 8\%); see Fig. 8.

Incoming logistics Terminal A1. In the disturbance scenario the percentage of lost chip and log trucks because of waiting in the queue for more than 90 minutes amounted to $3 \%$ of the total number of incoming chip trucks ("CT Over Waiting" and "LT Over Waiting"). The percentage of lost chip trucks because of storage overflow was 33\% of total incoming trucks ("CT Over Flow"); contrarily, no log trucks were lost because of overflow 

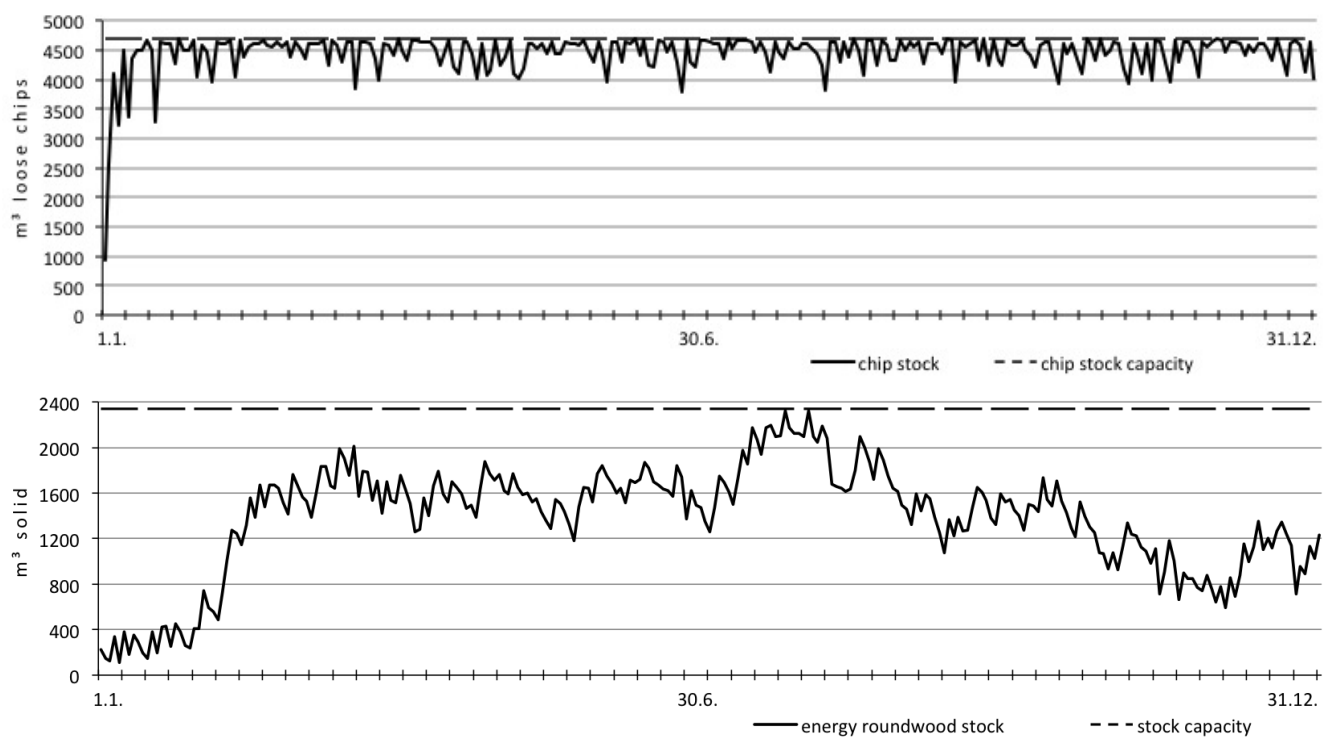

Figure 7 Terminal A2, disturbance scenario - stock development during the course of the year on a daily basis. N.B. Top diagram shows the chip stock; Bottom diagram shows the energy roundwood stock

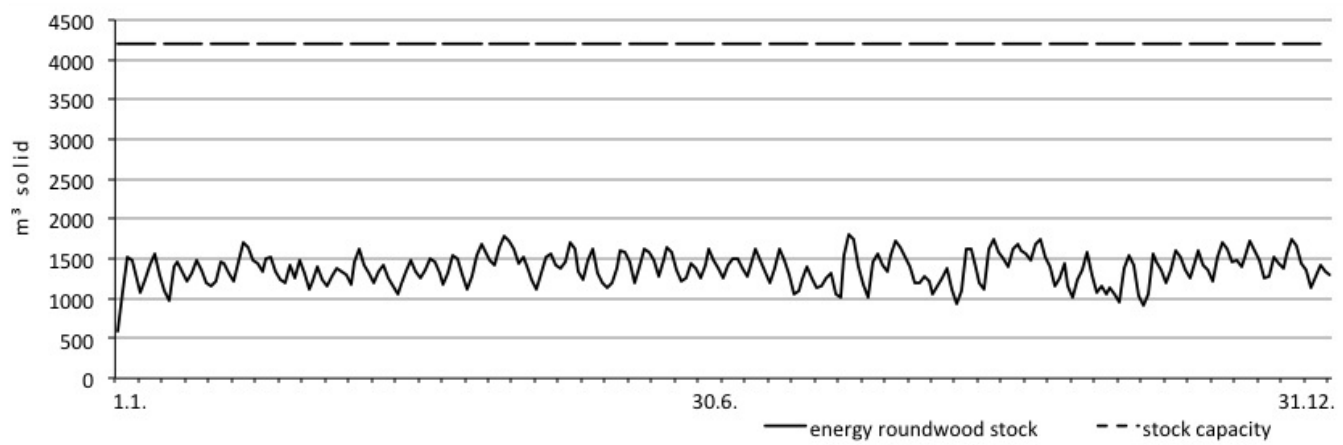

Figure 8 Energy roundwood stock development at Terminal B, disturbance scenario

("LT Over Flow"). Subsequently, the terminal fill rate equalled $64 \%$ for chip trucks and 97\% for log trucks ("Fill Rate CT" and "Fill Rate LT"). The mean lead time was 58 minutes (standard deviation 44\%) for chip trucks and 65 minutes (standard deviation 37\%) for log trucks. Mean waiting time in the queue was 22 minutes for chip trucks and 20 minutes for log trucks ("Mean CT Waiting Time" and "Mean LT Waiting Time").

Incoming logistics Terminal A2. In 158 the disturbance scenario the percentage of lost chip trucks because of waiting in the queue more than 90 minutes was 5\% ("CT Over Waiting") and $22 \%$ due to limited storage ("CT Over Flow"). The percentage of lost log trucks because of waiting in the queue more than 90 minutes was 5\% ("LT Over Waiting") and because of storage limits $0.5 \%$ ("LT Over Flow"). Subsequently, the terminal fill rate was $73 \%$ for chip trucks and $93.5 \%$ for log trucks. The mean lead time was 62 minutes (standard 
deviation 43\%) for chip trucks and 71 minutes (standard deviation 38\%) for log trucks. The mean waiting time in the queue was 26 minutes for chip trucks and 25 minutes for log trucks.

Incoming logistics Terminal B. In the disturbance scenario the percentage of lost trucks was $12 \%$ because of over waiting. However, no trucks were lost due to storage overflow. Thus, the terminal fill rate amounted to $88 \%$. The mean lead time was 81 minutes and the mean waiting time was 36 minutes. The discussed performance values are compiled in Table 6.

Train logistics in the terminals. In the disturbance scenario the maximum number of possible train arrivals per day changes, whereas the maximum number of wagons per train remains unchanged (due to length of sidings at the terminal), but only a block of 12 (A1) or 6 (A2) wagons can be ordered.
Due to non-business days, the terminal operated on 261 days in the observed year. Table 7 shows the average number of wagons per train and the number of arrivals in a year.

Material flow in the terminals. Table 8 shows the material flow in a one-year period. Note that when the material is chipped, $1 \mathrm{~m}^{3}$ energy roundwood yields $3 \mathrm{~m}^{3}$ of chips.

\section{Statistical results of full factorial experimen- tal design}

The modelled terminals have six factors (Terminal B has only three) that potentially influence eight performance values (Terminal B has only six) that are used in this statistical analysis. Studying the main effects (effect of one independent variable on a dependent variable) shows whether these factors (independent variables) influence the performance values (dependent variable). After simulation

Table 6 Incoming logistics per terminal, disturbance scenario

\begin{tabular}{lccl}
\hline Performance values & Disturbance scenario & \\
\hline & $\mathrm{A} 1$ & $\mathrm{~A} 2$ & $\mathrm{~B}$ \\
CT Over Waiting & $3 \%$ & $5 \%$ & - \\
CT Over Flow & $33 \%$ & $22 \%$ & $12 \%$ \\
LT Over Waiting & $3 \%$ & $5 \%$ & $0 \%$ \\
LT Over Flow & $0 \%$ & $0.5 \%$ & - \\
Mean CT Waiting Time & $58 \mathrm{~min}$ & $26 \mathrm{~min}$ & $36 \mathrm{~min}$ \\
Mean LT Waiting Time & $65 \mathrm{~min}$ & $25 \mathrm{~min}$ & - \\
Fill Rate CT & $64 \%$ & $73 \%$ & $88 \%$ \\
Fill Rate LT & $97 \%$ & $93.5 \%$ & \\
\hline
\end{tabular}

Table 7 Train logistics disturbance scenario. N.B. the maximum number of wagons is always used

\begin{tabular}{llll}
\hline Terminal & $\begin{array}{l}\text { Max. number of trains per } \\
\text { day }\end{array}$ & $\begin{array}{l}\text { Max. number of wagons per } \\
\text { train }\end{array}$ & Train arrivals total \\
\hline A1 & 2 & 12 (fixed number) & 153 \\
A2 & 2 & 6 (fixed number) & 387 \\
B & 2 & 6 (fixed number) & 397 \\
\hline
\end{tabular}

Table 8 Material flow in the terminals, regular scenario

\begin{tabular}{lccllc}
\hline Terminal & $\begin{array}{l}\text { Input } \\
\text { chips }\left(\mathrm{m}^{3}\right)\end{array}$ & $\begin{array}{l}\text { Input energy } \\
\text { roundwood }\left(\mathrm{m}^{3}\right)\end{array}$ & Output chips $\left(\mathrm{m}^{3}\right)$ & $\begin{array}{l}\text { Storage chips } \\
\left(\mathrm{m}^{3}\right)\end{array}$ & $\begin{array}{l}\text { Storage energy } \\
\text { roundwood }\left(\mathrm{m}^{3}\right)\end{array}$ \\
\hline A1 & 80,526 & 62,431 & 261,891 & 3,435 & 831,000 \\
A2 & 155,401 & 60,990 & 330,678 & 4,003 & 1,230 \\
B & & 115,634 & 343,008 & & 1,298 \\
\hline
\end{tabular}


runs and data collection an analysis of variance (ANOVA) was calculated. To determine whether a main effect is significant or not, a calculated p-value at a threshold of 0.05 was applied to indicate statistical significance. Due to the number of both independent and dependent variables used in the simulation the main effects are shown as a summary in Table 9. However, observing only one factor in the behaviour of the responses does not consider any statistical interactions. Such interactions occur when the effect of one factor alters in dependence on the level of another factor (Callahan et al. 2006). Subsequently, first order interactions were calculated and the statistical significance was indicated. A summary of first order interactions is shown in Table 10.

\section{Discussion}

The purpose of this study was to investigate if existing railway sidings for wood transport in
Austria can be adapted to provide multimodal transhipment hubs for PFF transport. Accordingly, three potential rail terminal layouts were explored and incoming material flows via road transport and outgoing flows via train were simulated. Number and frequency of incoming trucks and outgoing train wagons, storage capacities, performance of unloading, chipping and loading were simulated under two forest fuel market scenarios: regular and disturbance (cf. Rauch 2010). The simulation results provide daily, weekly, monthly and annual values for transhipment capacities and reveal bottlenecks in the terminal layout. On terminals with chip and log storage the chip storage is a limiting factor in the base scenario. Furthermore, in the disturbance scenario - although we assumed larger storage areas - the amount of trucks that could be dispatched, because the storage capacity was at its limit, would be unacceptable in actual practise. Doubling the number of arriving trucks in the disturbance scenario led to an increase in waiting times

Table 9 Summary table of the main effects of all three terminals

\begin{tabular}{|c|c|c|c|c|c|c|c|}
\hline & & $\begin{array}{c}\text { Chip } \\
\text { stock } \\
\text { capacity }\end{array}$ & $\begin{array}{c}\text { Round } \\
\text { wood } \\
\text { stock } \\
\text { capacity }\end{array}$ & $\begin{array}{c}\text { Chip } \\
\text { trucks per } \\
\text { day }\end{array}$ & $\begin{array}{c}\text { Round } \\
\text { wood } \\
\text { trucks per } \\
\text { day }\end{array}$ & $\begin{array}{l}\text { Number } \\
\text { of train } \\
\text { per day }\end{array}$ & $\begin{array}{c}\text { Type of } \\
\text { train }\end{array}$ \\
\hline \multirow{8}{*}{$\begin{array}{l}\text { Terminal } \\
\text { A1 }\end{array}$} & Lost CT Over Waiting & $0.000^{*}$ & 0.374 & $0.000^{*}$ & $0.000 *$ & $0.001 *$ & $0.000^{*}$ \\
\hline & Lost CT Over Flow & $0.000 *$ & 0.642 & $0.000^{*}$ & $0.000 *$ & $0.000 *$ & $0.000 *$ \\
\hline & Lost LT Over Waiting & $0.000 *$ & 0.404 & $0.000^{*}$ & $0.000 *$ & 0.003 & $0.000 *$ \\
\hline & Lost LT Over Flow & $0.000 *$ & 0.444 & $0.000^{*}$ & $0.000 *$ & $0.000 *$ & $0.000 *$ \\
\hline & Mean CT Waiting Time & $0.000 *$ & 0.065 & $0.000^{*}$ & $0.000 *$ & $0.003 *$ & $0.000 *$ \\
\hline & Mean LT Waiting Time & $0.000 *$ & 0.277 & $0.000 *$ & $0.000 *$ & $0.030 *$ & $0.000 *$ \\
\hline & Number of trains & $0.000 *$ & 0.223 & $0.000 *$ & $0.000 *$ & $0.000 *$ & $0.000 *$ \\
\hline & Chips out & $0.000 *$ & 0.766 & $0.000 *$ & $0.000 *$ & $0.000 *$ & $0.000 *$ \\
\hline \multirow{8}{*}{$\begin{array}{l}\text { Terminal } \\
\text { A2 }\end{array}$} & Lost CT Over Waiting & $0.000 *$ & 0.573 & $0.000 *$ & $0.000 *$ & $0.000 *$ & $0.000 *$ \\
\hline & Lost CT Over Flow & $0.000 *$ & 0.853 & $0.000^{*}$ & $0.000 *$ & $0.000 *$ & $0.000 *$ \\
\hline & Lost LT Over Waiting & $0.000 *$ & 0.891 & $0.000 *$ & $0.000 *$ & $0.000 *$ & $0.000 *$ \\
\hline & Lost LT Over Flow & $0.000 *$ & 0.853 & $0.000 *$ & $0.000 *$ & $0.000 *$ & $0.000 *$ \\
\hline & Mean CT Waiting Time & $0.000 *$ & 0.548 & $0.000^{*}$ & $0.000 *$ & $0.000 *$ & $0.000 *$ \\
\hline & Mean LT Waiting Time & $0.000 *$ & 0.66 & $0.000 *$ & $0.000 *$ & $0.000 *$ & $0.000 *$ \\
\hline & Number of trains & $0.000 *$ & 0.851 & $0.000^{*}$ & $0.000 *$ & $0.000 *$ & $0.000 *$ \\
\hline & Chips out & $0.000 *$ & 0.732 & $0.000 *$ & $0.000^{*}$ & $0.000 *$ & $0.000 *$ \\
\hline \multirow{5}{*}{ Terminal B } & Lost LT Over Waiting & & 0.435 & & $0.000^{*}$ & $0.000 *$ & \\
\hline & Lost LT Over Flow & & $0.006^{*}$ & & $0.000 *$ & $0.000 *$ & \\
\hline & Mean LT Waiting Time & & 0.219 & & $0.000 *$ & $0.000 *$ & \\
\hline & Number of trains & & 0.666 & & $0.000 *$ & $0.000 *$ & \\
\hline & Chips out & & 0.666 & & $0.000 *$ & $0.000 *$ & \\
\hline
\end{tabular}

Note. Significant effects $(p<0.05)$ are indicated with * 


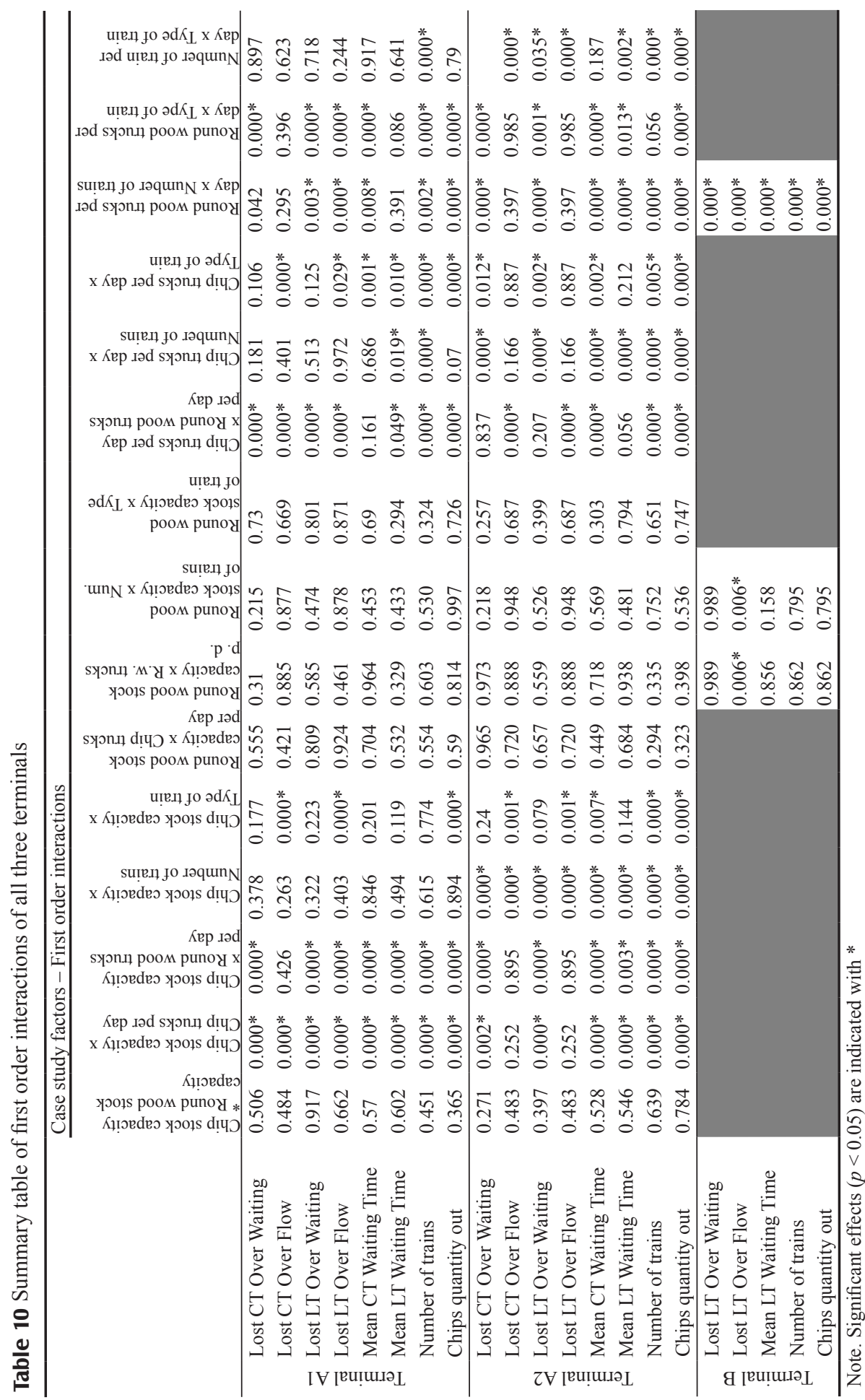


and thus more trucks were sent away due to over waiting. This bottleneck may be avoided by changing the layout so that there is more than one entrance way.

In contrast to terminals A1 and A2, chip storage for Terminal B was not modelled, because the available area was too small. Chip storage areas should be paved to avoid contaminations with soil and stones and to facilitate wheel loader operations. Therefore, investment costs are much higher compared to roundwood storage areas, for which gravel surfaces are also suitable. As practical experience teaches us, high investment costs are the main barrier to establish innovations in the PFF supply chain (Wolfsmayr \& Rauch 2014b). In many cases, the available railway sidings in Austria do not provide paved surfaces that are large enough to setup a chip storage. According to the simulation a 2,500 $\mathrm{m}^{3}$ storage was well used when 3 trucks deliver $270 \mathrm{~m}^{3}$ chips per day. Taking this into account, a terminal without chip storage and wheel loader operations was modelled, too. The system used in terminal B does not need infrastructure investments nor is a wheel loader necessary, because loading is performed by directly chipping into containers (WoodTainer XXL) situated on train wagons. However, if paved ground is available it should be preferred, even for roundwood storage, since dirt and contamination can be avoided.

In the statistical analyses, both the main effects and the first order interactions showed that - with the exception of the energy roundwood stock capacity - case study factors significantly influence performance values. The reason is that the storage area for uncomminuted material is quite high compared with chip storage in the simulation.

Concisely speaking, the regular scenario shows that existing railway sidings can be effectively used as PFF transhipment hubs providing a fill rate of between $93.6 \%$ and $99.7 \%$, and a total annual output of 150,000 to 200,000 $\mathrm{m}^{3}$ wood chip shipped via train.

However, even with increased storage possibilities it is ineffective to use existing loading 162 sidings for a transhipment of 20 trucks per day, since it is impossible to send away one third of the arriving trucks; thus performance values indicate that such high volumes cannot be handled if the conditions of current scenarios hold. The storage area at terminal B (energy roundwood only) could more easily cope with doubling the incoming flows. Contrarily, truck unloading times were higher for uncomminuted material and thus led to fairly long waiting times in the queue ("LT Over Waiting" = 12\%). This might be acceptable for a short time, but not for a period of several months.

Simulation results revealed that chip storage areas should be as large as possible, since the utilisation was under both scenarios much higher than the utilisation of the roundwood storage in both terminals, A1 and A2. Contrarily, at many sites it would be easier to store only uncomminuted material, because paved ground is not required.

\section{Conclusion}

On the one hand the simulation shows that under Austrian circumstances it is possible to use existing rail sidings for a PFF terminal and tranship fairly high volumes to bioenergy plants. On the other hand it highlights that there are limitations in the volumes, which can be transhipped because of the existing infrastructure.

A benefit of such a train terminal is to keep pre-haulage distance short, which is especially important for PFF assortments with low weight and high volumes (e.g. tops and tree sections with attached branches). Therefore, train terminals can be important means to increase the use of these assortments and to enlarge the PFF assortment mix of bioenergy plants. Moreover, pre-concentration at a terminal and main-haulage via volume optimized container wagons can increase the economically viable transport distance.

Further investigations on PFF terminals should include seasonality in the demands of 
heating plants (e.g. higher demand in winter) and the supply of the forest (reduced access to mountain forests during winter). Moreover, stochastic events could be given more importance: breakdown of chipper or wheel loader, container wagons that are not available in time, periods with undersupply due to impassable forest roads after heavy snow or rain fall. Additionally, the types of vehicles for road prehaulage could be extended, i.e. include tractortrailer units for both roundwood and residues as well as for chips.

\section{Acknowledgement}

The authors would like to thank Karl Etlinger (BOKU) and Hannes Pichler (Innofreight) for their valuable input. This research was carried out in the framework of the project "InTraHo" supported by the programme I2V (Austrian Ministry for Transport, Innovation and Technology).

\section{References}

Anbumozhi V., Gunjima T., Prem Ananth A., Visvanathan C., 2010. An assessment of inter-firm networks in a wood biomass industrial cluster: lessons for integrated policymaking. Clean Technologies and Environmental Policy 12: 365-372. DOI:10.1007/s10098-009-0246-z.

Austrian Biomass Association, 2013. Basisdaten Bioenergie 2013 [Basic data bioenergy 2013]. Vienna, 52 p.

Behrends S., 2012. The Significance of the Urban Context for the Sustainability Performance of Intermodal Roadrail Transport. Procedia - Social and Behavioral Sciences 54: 375-386. DOI:10.1016/j.sbspro.2012.09.757.

Börjesson P., Gustavsson L., 1996. Regional production and utilization of biomass in Sweden. Energy 21: 747-764. DOI: 10.1016/0360-5442(96)00029-1. DOI:10.1016/0360-5442(96)00029-1.

Callahan R.N., Hubbard K.M., Bacoski N.M., 2006. The use of simulation modeling and factorial analysis as a method for process flow improvement. The International Journal of Advanced Manufacturing Technology 29: 202-208. DOI:10.1007/s00170-004-2497-5.

Dornburg V., Faaij A.P.C., 2001. Efficiency and economy of wood-fired biomass energy systems in relation to scale regarding heat and power generation using combustion and gasification technologies. Biomass and Bioenergy
21: 91-108. DOI:10.1016/S0961-9534(01)00030-7.

Etlinger K., Rauch P., Gronalt M., 2014. Improving rail road terminal operations in the forest wood supply chain - a simualtion based approach. In: Bruzzone, Del Rio Vilas, Longo, Merkuryev, Piera (eds.), Proceedings of the International Conference on Harbor Maritime and Multimodal Logistics M\&S 2014, pp. 199-206.

FOROPA, 2014. Web: http://www.foropa.eu/. Accessed 2014-03-05.

Gan J., Smith C.T., 2011. Optimal plant size and feedstock supply radius: A modeling approach to minimize bioenergy production costs. Biomass and Bioenergy 35: 3350-3359. DOI:10.1016/j.biombioe.2010.08.062.

Gronalt M., Rauch P., 2007. Designing a regional forest fuel supply network. Biomass and Bioenergy 31: 393402. DOI:10.1016/j.biombioe.2007.01.007.

Hamelinck C.N., Suurs R.A.A., Faaij A.P.C., 2005. International bioenergy transport costs and energy balance. Biomass and Bioenergy 29: 114-134. DOI:10.1016/ j.biombioe.2005.04.002.

Haneder H., Furtner K., 2013. Biomasse-Heizungserhebung 2013 [Survey on biomass heating 2013]. Landwirtschaftskammer Niederösterreich, St. Pölten, 20 p.

Innofreight, 2013. Web: http://www.innofreight.at. Accessed 2013-04-18.

Jäppinen E., Korpinen O.-J., Ranta T., 2013. GHG emissions of forest-biomass supply chains to commercialscale liquid-biofuel production plants in Finland. GCB Bioenergy 6: 290-299. DOI:10.1111/gcbb.12048.

Jenkins T.L., Sutherland J.W., 2014. A cost model for forest-based biofuel production and its application to optimal facility size determination. Forest Policy and Economics 38: 32-39. DOI:10.1016/j.forpol.2013.08.004.

Junginger M., Faaij A., van den Broek R., Koopmans A., Hulscher W., 2001. Fuel supply strategies for largescale bio-energy projects in developing countries. Electricity generation from agricultural and forest residues in Northeastern Thailand. Biomass and Bioenergy 21: 259-275. DOI:10.1016/S0961-9534(01)00034-4.

Lindholm E.-L., Berg S., 2005. Energy requirement and environmental impact in timber transport. Scandinavian Journal of Forest Research 20: 184-191. DOI:10.1080/ 02827580510008329.

Lundmark R., 2006. Cost structure of and competition for forest-based biomass. Scandinavian Journal of Forest Research 21: 272-280. DOI:10.1080/02827580600688 251.

Madlener R., Bachhiesl M., 2007. Socio-economic drivers of large urban biomass cogeneration: Sustainable energy supply for Austria's capital Vienna. Energy Policy 35: 1075-1087. DOI:10.1016/j.enpol.2006.01.022.

Madlener R., Vögtli S., 2008. Diffusion of bioenergy in urban areas: A socio-economic analysis of the Swiss woodfired cogeneration plant in Basel. Biomass and Bioenergy 32: 815-828. DOI:10.1016/j.biombioe.2008.01.006.

Ranta T., Rinne S., 2006. The profitability of transporting uncomminuted raw materials in Finland. Biomass and Bioenergy 30: 231-237. DOI:10.1016/ 
j.biombioe.2005.11.012.

Rauch P., 2010. Stochastic simulation of forest fuel sourcing models under risk. Scandinavian Journal of Forest Research 25: 574-584. DOI:10.1080/02827581.2010.5 12876.

Rauch P., Gronalt M., 2010. The terminal location problem in a cooperative forest fuel supply network. International Journal of Forest Engineering 21: 32-40. DOI: 10.1080/14942119.2010.10702596.

Sauter P., Witt J., Billig E., Thrän D., 2013. Impact of the Renewable Energy Sources Act in Germany on electricity produced with solid biofuels - Lessons learned by monitoring the market development. Biomass and Bioenergy 53: 162-171. DOI:10.1016/j.biombioe. 2013.01.014.

Searcy E., Flynn P., Ghafoori E., Kumar A., 2007. The relative cost of biomass energy transport. Applied Biochemistry and Biotechnology 137-140: 639-652. DOI:10.1007/s12010-007-9085-8.

Tahvanainen T., Anttila P., 2011. Supply chain cost analysis of long-distance transportation of energy wood in Finland. Biomass and Bioenergy 35: 3360-3375. DOI:10.1016/j.biombioe. 2010.11.014
Wolfsmayr U., Rauch P., Gronalt M., 2013. Endbericht Intermodales Transportsystem Holzbiomasse (unveröffentlicht) [Final project report intermodal transport system woody biomass (unpublished)]. Universität für Bodenkultur, Wien.

Wolfsmayr U.J., Rauch P., 2013. Transportketten forstlicher Biomasse - Stand der Technik und Innovationen [Primary forest fuel transport chains - state of the art and innovations]. Schweizerische Zeitschrift fur Forstwesen 164: 365-373. DOI:10.3188/szf. 2013.0365.

Wolfsmayr U.J., Rauch P., 2014a. The primary forest fuel supply chain: A literature review. Biomass and Bioenergy 60: 203-221. DOI:10.1016/j.biombioe.2013.10.025

Wolfsmayr U.J., Rauch P., 2014b. Primary forest fuel supply chain: assessing barriers and drivers for the modal shift from truck to train. Silva Fennica 48. DOI:10.14214/sf.1217.

Wolfsmayr U.J., Rauch P., 2014c. Strategy development for regional forest fuel supply chains in Southeast $\mathrm{Eu}-$ rope. In: Austrian Biomass Association (ed.), Central European biomass conference. Austrian Biomass Association, Graz. 